\title{
Investigation of the relation between bridge pier scour depth and vertical velocity component
}

\author{
Köprü ayağı oyulma derinliği ile düşey hız bileşeni arasındaki ilişkinin \\ araștırılması
}

\author{
Oğuz Kağan ÇETíN ${ }^{1}$, Can SAÇAN ${ }^{1}$, Gökçen BOMBAR ${ }^{*}$ \\ ${ }^{1}$ GAMA Güç Sistemleri Mühendislik ve Taahhüt A.Ş., Ankara, Turkey. \\ oguz.cetin@gama.com.tr, can.sacan@gama.com.tr \\ ${ }^{2}$ Civil Engineering Department, Faculty of Engineering and Architecture, İzmir Katip Çelebi University, İzmir, Turkey. \\ gokcen.bombar@ikc.edu.tr
}

Received/Geliş Tarihi: 13.08.2015, Accepted/Kabul Tarihi: 03.11.2015

* Corresponding author/Yazıșllan Yazar

doi: $10.5505 /$ pajes.2015.76768

Research Article/Arastırma Makalesi

\section{Abstract}

Local scour around bridge piers and its consequences can be considered as an important engineering problem. This study was conducted in a 18 $m$ long and $70 \mathrm{~cm}$ wide rectangular flume with sediment median diameter of $0.43 \mathrm{~mm}$ by using two bridge piers having diameters of $6 \mathrm{~cm}$ and $9 \mathrm{~cm}$. The duration of 5 experiments were limited to 4 hours. During the experiments, the evolution of scour depth $\left(d_{s}\right)$ and the threedimensional velocity at $4 \mathrm{~cm}$ above the bottom and $6 \mathrm{~cm}$ upstream part of the bridge pier was recorded as a function of time. The relationship between the vertical velocity component $\left(V_{z}\right)$ and scouring depth was investigated and an equation for the dimensionless forms of these parameters was proposed. It is observed that the proposed relation is in accord with the limited data found in literature.

Keywords: Bridge pier, Scour depth, Vertical velocity, Time evolution
Öz

Köprü ayakları etrafinda oluşan yerel oyulmalar önemli bir mühendislik problemi olarak kabul edilmektedir. Bu çalışmada, $6 \mathrm{~cm}$ ve $9 \mathrm{~cm}$ çapa sahip iki köprü ayağı, içinde $0.43 \mathrm{~mm}$ medyan dane çapında sediment bulunan $18 \mathrm{~m}$ uzuluğunda ve $70 \mathrm{~cm}$ genişliğinde dikdörtgen kesitli bir kanal içine yerleștirilmiș ve bu ayaklar etrafinda olușan oyulmalar ölçülmüștür. Her biri 4 saat sürdürülen 5 adet deney gerçeklestirilmiștir. Deneyler sırasında, oyulma derinliğinin zamanla değisimi $\left(d_{s}\right)$ ve ayağın $6 \mathrm{~cm}$ membasında tabandan $4 \mathrm{~cm}$ yukarıdaki noktasal hız değişimi zamana bağlı olarak kaydedilmiştir. Düşey hız bileșeni $\left(V_{z}\right)$ ile oyulma derinliği arasındaki iliski arastırılmıs ve bu parametrelerin boyutsuz biçimleri için bir denklem önerilmiștir. Sözkonusu bağıntının, literatürde bulunan sınırlı miktardaki çalıșmaya ait veri ile uyum içinde olduğu görülmektedir.

Anahtar kelimeler: Köprü ayağı, Oyulma derinliği, Düșey hız, Zamanla değișim

bottom. Velocity component in the vertical direction interacts with the component in horizontal direction and causes the vortex formation which is termed as the horseshoe vortex. The horseshoe vortex passing around the piers causes the transport of sediments which are already mobilized by the vertical down flow [10]. Approach flow velocity is significantly effective on the scour depth around bridge piers; especially the vertical velocity component of the flow in front of the pier is defined as one of the factors responsible for scour.

The stream-wise and vertical velocity components, turbulence intensity and vorticity have been investigated for the nonscoured fixed base in the flow field around the pier [11]-[14]. Dargahi (1990) investigated the structure of the horseshoe vortex by using the hydrogen bubble technique and Preston tube [15]. The earliest known study on the relationship between horseshoe vortex and scour hole was conducted by Melville (1975) and Melville and Raudkivi (1977) [16],[17]. Qadar (1981) studied the interaction between the horseshoe vortex and the evolution of the scour depth [18]. He proposed a circular vortex having a diameter proportional to the scour depth. Muzzammil and Gangadharaiah (2003) visually studied the vortex in front of the bridge pier and revealed that it has an elliptical shape [19]. Then they related its strength and size to the hydraulic and geometrical properties of flow. Sarker (1998) studied the flow characteristics around cylindrical piers on a scoured bed under various wave-current combinations by using an Acoustic Doppler Velocimetry (ADV) [20]. Ahmed and sudden decrease in velocity occurs. The fluid particles hit the bridge surface, lose their speed and start moving towards the 
Rajaratnam (1998) studied velocity distribution around the circular pier placed on smooth, rough and mobile beds [21]. Istiarto (2001) has determined experimentally the velocity, turbulence intensity, turbulent kinetic energy and bottom shear stress distribution around the circular bridge [22]. Afterwards, Dey and Raikar (2007) and Das et al. (2013) examined the flow field and turbulence characteristics with ADV around the circular and square bridge piers at scour depths of $25 \%, 50 \%, 75 \%$ and $100 \%$ of the equilibrium scour depths [23],[24]. Unger and Hager (2007) used Particle Image Velocimetry (PIV) in examining the flow field characteristics [25]. Diab et al. (2009) worked with square bridge piers [26].

The studies that correlate the scour depths to the velocity profiles obtained at the same instant are quite limited. In the literature, most of the velocity measurements were conducted when the scour depth reached to its equilibrium value. Others did the measurements at various times at which the scour pit geometry was fixed by a chemical substance (such as cement) and velocity was not obtained at the time of scouring in a simultaneous manner. In this study, the temporal evolution of scour depth $\left(d_{s}\right)$ and vertical velocity component $\left(V_{z}\right)$ at $4 \mathrm{~cm}$ above the bed and $6 \mathrm{~cm}$ upstream of the bridge piers was determined at an extreme location of the instrument closest to the bed and the bridge pier. Two bridge piers having diameters of $6 \mathrm{~cm}$ and $9 \mathrm{~cm}$ were tested. In total 5 experiments were conducted, each continued for 4 hours. Data were grouped according to the non-dimensional coordinates of the points $\mathrm{A} \& \mathrm{~B}$ obtained by dividing them by flow depth and bridge diameter (see Table 1) where the velocity measurements were carried out. The vertical velocity component and the depth of scour were made dimensionless and a relationship was sought between them. The experimental results were compared and interpreted with similar studies in the literature.

\section{Experimental set-up}

The experiments were carried out in a rectangular flume which was $70 \mathrm{~cm}$ wide, $60 \mathrm{~cm}$ high and $18 \mathrm{~m}$ long. The slope of the flume was 0.004 . The facility was located at the Hydraulics Laboratory of Department of Civil Engineering in Ege University (Figure 1a). The flume has transparent plexiglas sidewalls. The water depths were adjusted to the desired depth so that clear-water conditions were maintained by the use of the tail gate at the end section (Figure $1 \mathrm{~b}$ ). The main tank was located at the downstream part of the flume, behind the wall and outside the building. Its height was approximately $2.4 \mathrm{~m}$, and has the dimensions $7.2 \mathrm{~m} \times 3.6 \mathrm{~m}$ with a total volume of $47 \mathrm{~m}^{3}$. The water height was recorded and controlled by an ultrasonic instrument (Pulsar IMP+).

The experimental system has a supply line of $160 \mathrm{~mm}$ diameter and a pump having a maximum capacity of $100 \mathrm{l} / \mathrm{s}$ and a power of $45 \mathrm{~kW}$. On the supply line the discharge was measured by an electromagnetic flow meter (Krohne Optiflux) The measured values were recorded by a data logger (Brainchild) and computer. A stilling basin was located at the entrance of the flume having the dimensions of $200 \mathrm{~cm} \times 190 \mathrm{~cm} \times 91 \mathrm{~cm}$. The scheme of the flume is given in Figure 2.
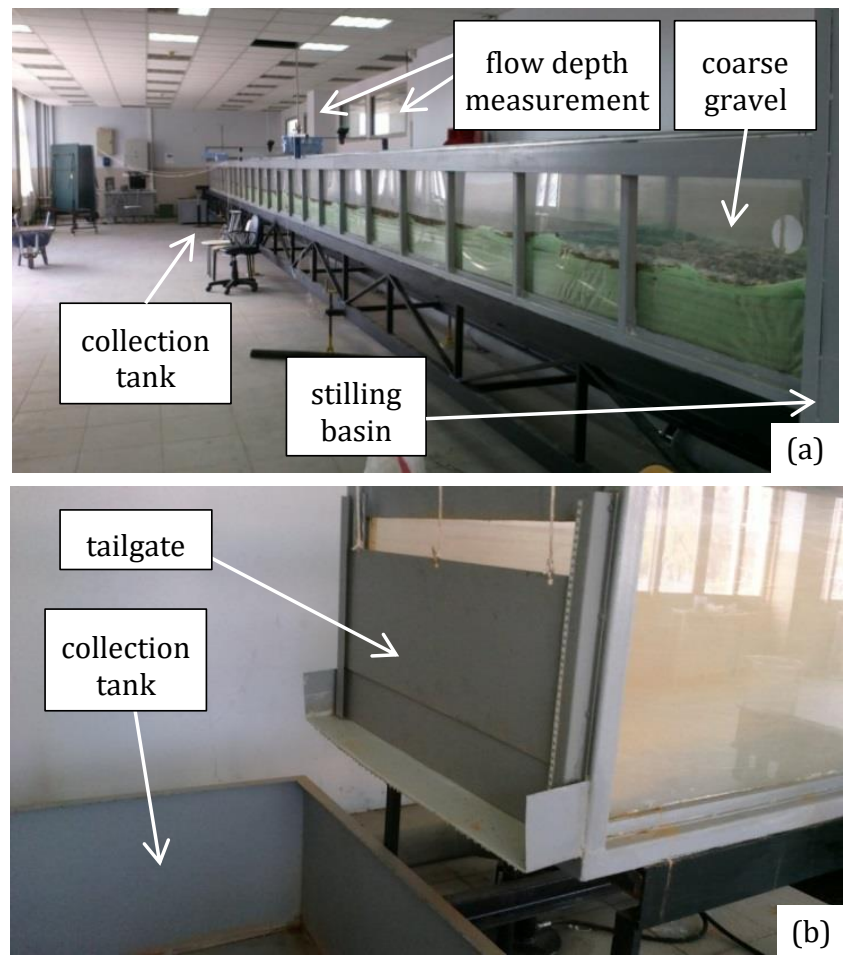

Figure 1: Flumes general view, (a): The upstream part,

(b): The tailgate and the collection tank at the downstream.

At the exit of the flume a collection tank serves as an intermediate unit to transmit the flow back to the main tank. A false floor was made on the flume bottom by placing bricks along the first $7.7 \mathrm{~m}$ and last $6.95 \mathrm{~m}$ of the flume as given in Figure 3(a) [27].

The space was filled with cohesionless fine sand of median diameter $\mathrm{d}_{50} 0.43 \mathrm{~mm}$. The $\mathrm{d}_{90}$ was $1.39 \mathrm{~mm}$ and geometric standard deviation was 2.27 [28]. The coefficient of uniformity $\mathrm{Cu}\left(=\mathrm{d}_{60} / \mathrm{d}_{10}\right)$ was calculated as 3.72 . The total depth of the sediment was $22 \mathrm{~cm}$ at the center of the flume. In order to develop a fully-turbulent flow and to prevent local scour at the flume entrance, coarse sediments were placed at the bed surface of the first $1.7 \mathrm{~m}$ of the flume as given in Figure 3(b). The circular bridge pier of diameters $6 \mathrm{~cm}$ and $9 \mathrm{~cm}$ were placed, one at a time, $9 \mathrm{~m}$ away from the flume entrance. Before the experiments, the flume bed was mixed to achieve homogeneity in the vertical and stream-wise directions and regular bed slope was formed by the mobile system shown in Figure 3(c).

Table 1: The details of the test conditions of the experiments.

\begin{tabular}{|c|c|c|c|c|c|c|c|c|c|c|c|}
\hline $\begin{array}{l}\text { Exp } \\
\text { No }\end{array}$ & $\begin{array}{c}B \\
(\mathrm{~cm})\end{array}$ & $\begin{array}{c}Q \\
(\mathrm{l} / \mathrm{s})\end{array}$ & $\begin{array}{c}H_{k} \\
(\mathrm{~cm})\end{array}$ & $\begin{array}{c}V \\
(\mathrm{~cm} / \mathrm{s})\end{array}$ & $\frac{(l+b / 2)}{b}$ & $\frac{z_{H}}{H_{k}}$ & $\begin{array}{l}\text { Point } \\
\text { Name }\end{array}$ & $\begin{array}{c}V_{c} \\
(\mathrm{~cm} / \mathrm{s})\end{array}$ & $V / V_{c}$ & $\operatorname{Re}=\frac{V b}{v}$ & $F r=\frac{V}{\sqrt{g H_{k}}}$ \\
\hline D1 & 6 & 30.8 & 18.9 & 23.3 & 1.50 & 0.2 & $\mathrm{~A}$ & 29.9 & 0.78 & 13980 & 0.17 \\
\hline D2 & 6 & 38.9 & 20.3 & 27.4 & 1.50 & 0.2 & A & 30.1 & 0.91 & 16440 & 0.19 \\
\hline D3 & 6 & 36.2 & 19.8 & 26.1 & 1.50 & 0.2 & A & 30.0 & 0.87 & 15660 & 0.19 \\
\hline D4 & 6 & 38.5 & 20.4 & 27.0 & 1.50 & 0.2 & A & 30.1 & 0.90 & 16200 & 0.19 \\
\hline D5 & 9 & 38.7 & 20.3 & 27.3 & 1.17 & 0.2 & $\mathrm{~B}$ & 30.1 & 0.91 & 24570 & 0.19 \\
\hline
\end{tabular}




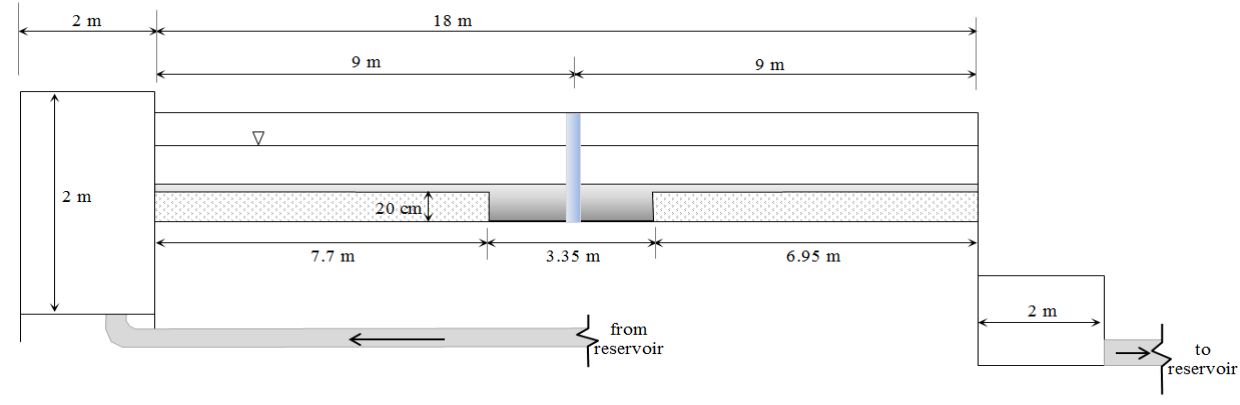

Figure 2: The scheme of the experimental set-up.

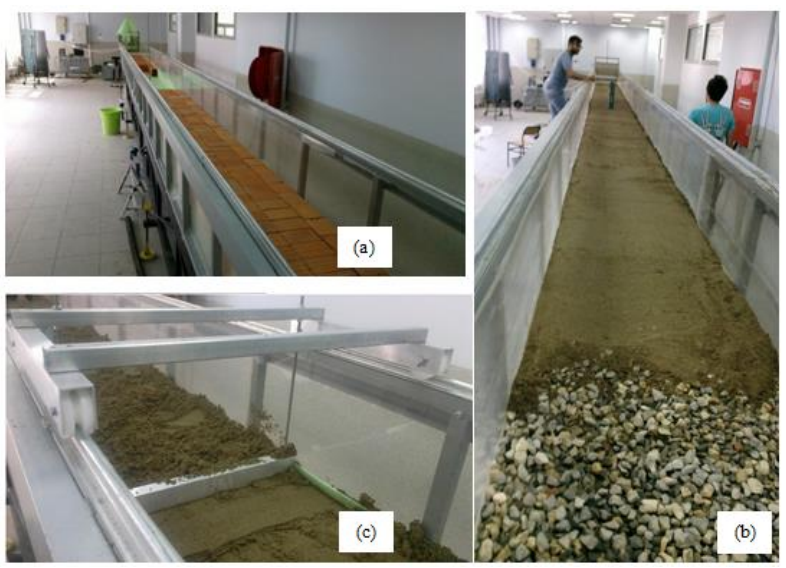

Figure 3: (a): Arrangement of the bricks along the flume,

(b): The coarse gravels at the entrance of the flume,

(c): The mobile system used to form the bed slope.

The instantaneous point velocities were measured by means of a side looking ultrasonic instrument (Sontek Flow Tracker). The sound waves with high velocity were emitted from the core center of the instrument and the reflected waves were received by the three sensor arms. According to the Doppler principle, the velocity of flow was obtained [29]. The cylindrical sampling volume was $0.25 \mathrm{~cm}^{3}$ and located $10 \mathrm{~cm}$ away from the sensor. The sampling frequency of all instruments was $1 \mathrm{~Hz}$.

\section{Experimental Procedure}

In total 5 experiments were performed with two bridge piers having diameters $6 \mathrm{~cm}$ and $9 \mathrm{~cm}$ to determine the relationship between the vertical velocity in front of the bridge pier and the scour depth during the development of the scour. The experimental conditions were summarized in Table 1 . Here $b$ is the pier width, $Q$ is the discharge, $H_{k}$ is the approach flow depth measured $30 \mathrm{~cm}$ upstream of the piers, $V$ is the approach velocity calculated by using $Q$ and $H_{k}$. The vertical distance between the point where the velocity measurements were conducted and the undisturbed bed is defined as $z_{H}$ and the distance between the measurement point and the front of the bridge pier is referred as $l$. The coordinates were made dimensionless as $z_{H} / H_{k}$ and $(l+b / 2) / b$ (see Figure 4$)$. This makes the measurements D1-D4 conducted at point $\mathrm{A}(1.50,0.20)$ and measurement $\mathrm{D} 5$ at $\mathrm{B}(1.17,0.20)$. The critical velocity $V_{c}$ is determined from the logarithmic form of the velocity profile as follows [27]:

$$
\frac{V_{c}}{u_{*_{c}}}=5.75 \log \left(5.53 \frac{H_{k}}{d_{50}}\right)
$$

Here $u_{* c}$ denotes the critical shear velocity that may be calculated by using the following equation based on the Shields diagram and valid for $0.1 \mathrm{~mm}<d_{50}<1 \mathrm{~mm}$, where $u_{* c}$ is in $\mathrm{m} / \mathrm{s}$ and $d_{50}$ is in $\mathrm{mm}$ [27]:

$u_{*_{c}}=0.0115+0.0125 d_{50}^{1.4}$

Reynolds number Reynolds number $\mathrm{Re}=V b / v$ and Froude number $\mathrm{Fr}=\mathrm{V} / \sqrt{g H_{k}}$ which are based on pier diameter and approaching velocity are calculated. Here $v$ is the kinematic viscosity and $g$ is the gravitational acceleration.

A scale was glued at the side of the pier which was $70^{\circ}$ downstream from the channel axis. The time evolution of scour was recorded by a waterproof camera placed at the rear side of the pier close to the water surface. The maximum scour depth was observed at this side for all experiments. The locations of the points for scour depth and velocity were depicted in Figure 4.

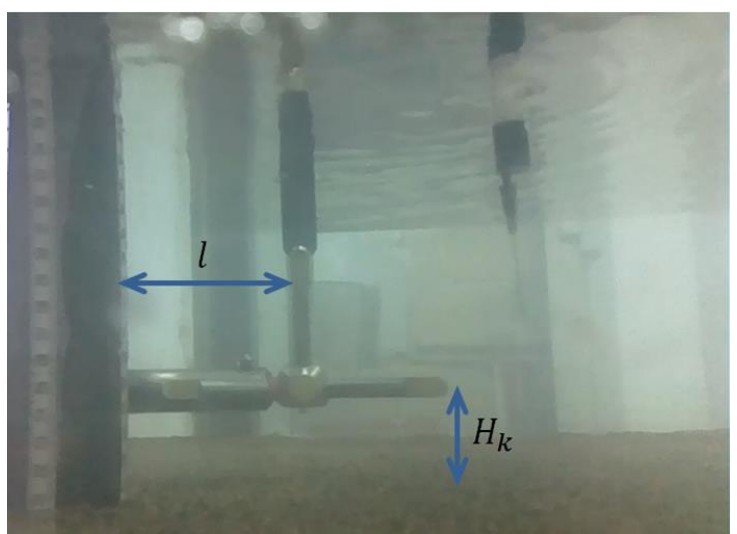

(a)

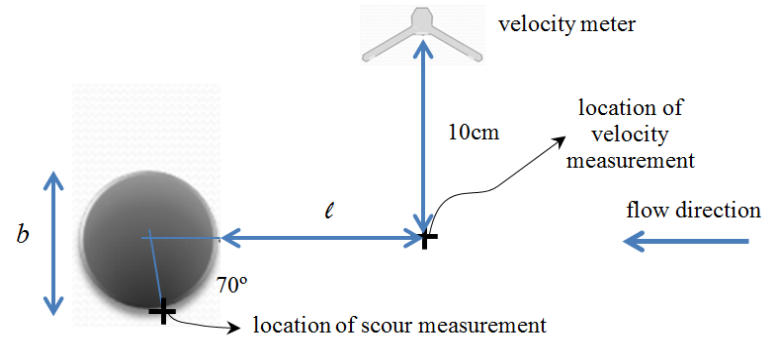

(b)

Figure 4: (a): Photo of pier and the instrument, (b): Plan view of the bridge pier showing the locations of the measurement points of velocity meter and scour. 
At the beginning of the experiments, the flow rate and the flow depth in the flume was increased gradually so that the initial scour was prevented. When the flow rate was reached to its predetermined value, the chronometer was set as $t=0$. All experiments continued for 4 hours. Within this period, in the first 30 minutes the scour depth was obtained more frequently and the velocity as well. During the rest of the test period the readings were obtained with 20 minute intervals. Each velocity measurement was continued for 300 seconds ( $2 \%$ of the total test duration) which is within the range of 60-573 seconds usually adopted in literature as sampling time [22],[30]-[35].

Before each experiment the sediment around the bridge pier was mixed thoroughly, flattened and leveled in order to prevent the armor formation.

\section{Experimental Results}

In all experiments the velocity was measured for a period of 300 seconds at various times within the 4 hour test duration. The obtained point velocities in stream-wise direction $(u)$ and in vertical direction $(w)$ were averaged and the ensemble averages were calculated as $V_{x}$ and $V_{z}$, as given in Figure 5 and Figure 6, respectively. Here positive vertical velocity indicates the down flow.

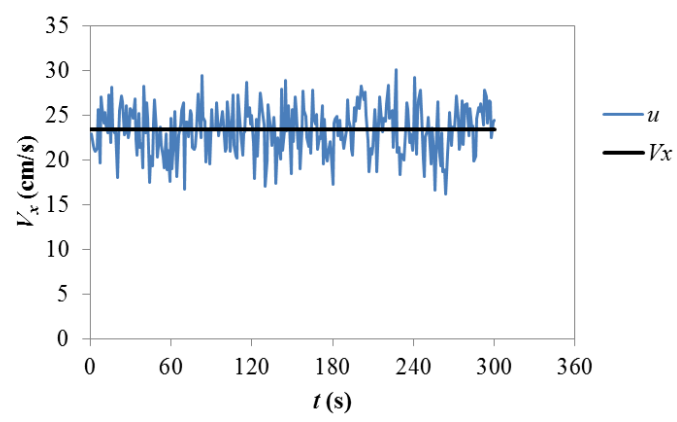

Figure 5: The time series of stream-wise component of the instantaneous point velocity $(u)$ and its ensemble average $\left(V_{x}\right)$.

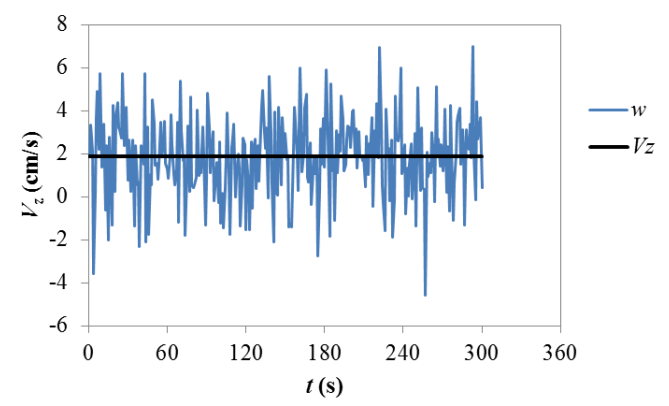

Figure 6: The time series of vertical component of the instantaneous point velocity $(w)$ and its ensemble average $\left(V_{z}\right)$.

The ensemble averages of the instantaneous point velocities in stream-wise and vertical directions $\left(V_{x}\right.$ and $\left.V_{z}\right)$ were obtained 1113 times throughout the test duration. The time variation of $V_{x}$ and $V_{z}$ are given in Figure 7 and Figure 8, respectively. It is observed that the stream-wise component $V_{x}$ was not changed within this 4 hours period. On the other hand, the vertical velocity component $V_{z}$ value had an increasing trend with time. The flow upstream encountered the bridge pier and the fluid particles start moving downward. Meanwhile, the increase in scour depth provides a broader space for the passage of the incoming fluid particles which are directed towards the bottom and freely continue moving around the pier further downstream.

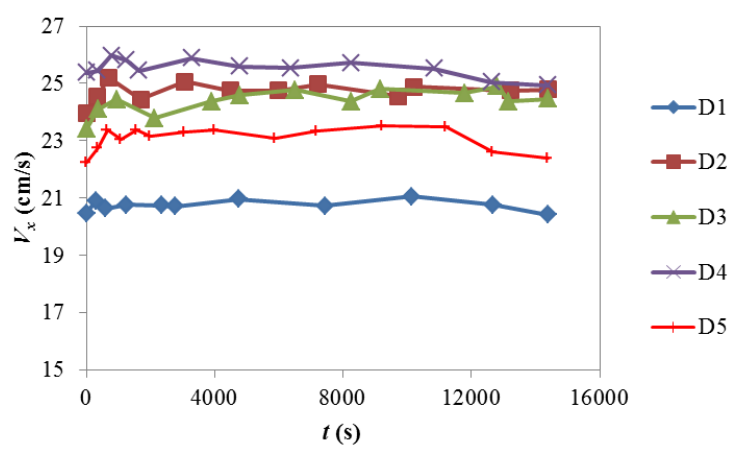

Figure 7: The variation of $V_{x}$ with time..

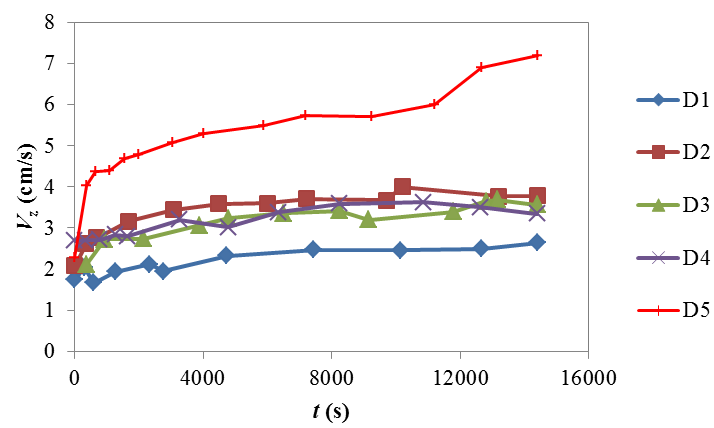

Figure 8: The variation of $V_{z}$ with time.

The variation of scour depth with time is given in Figure 9. A logarithmic trend line was imposed for each experiment. By using the equation obtained, the scour depths corresponding to the time of velocity measurement was calculated. In order to guarantee that equilibrium scour depth can be obtained by extrapolation of records to infinite time, the experiments shouldn't be shorter than one to two weeks [36]. Since the aim of the study was not to investigate the equilibrium scour depth $d_{s e}$, the tests were terminated after 4 hours and an equilibrium scour depth was not evaluated.

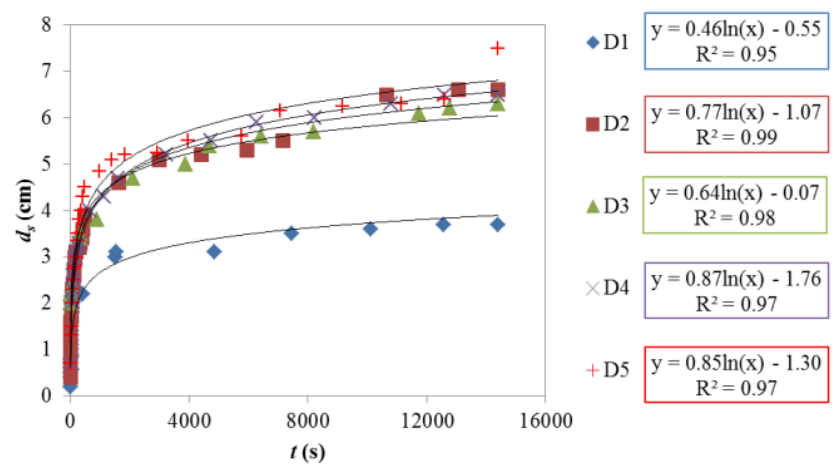

Figure 9: The variation of scour depth $d_{s}$, with time.

According to the equation of the logarithmic trend line given in Figure 9, the scour depths were calculated corresponding to instants at which the velocity measurements were executed. The measured $V_{z}$ values and the corresponding $d_{s}$ values are plotted in Figure 10. Here it is revealed that there is a linear relation between $V_{z}$ and $d_{s}$. The correlation coefficient $\mathrm{R}^{2}$ within the range of 0.69 0.94 (not shown in the figure), proposing that there is a strong relationship between these two parameters. 


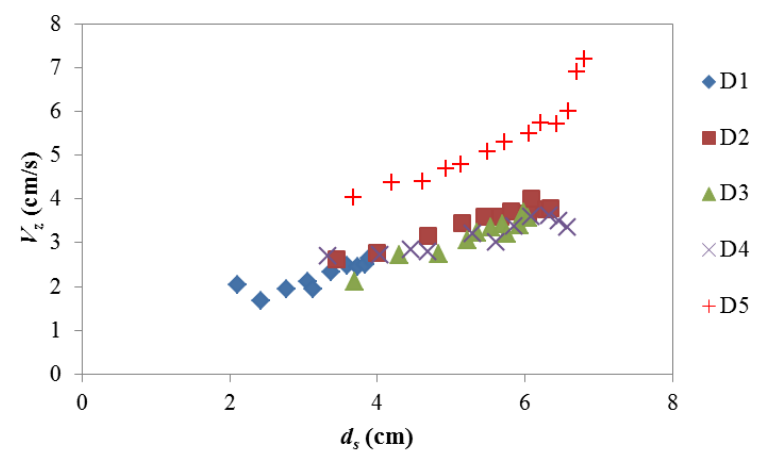

Figure 10: The variation of vertical velocity component $\left(V_{z}\right)$ with the scour depth $\left(d_{s}\right)$.

The vertical velocity component and the scour depth were made dimensionless as $V_{z} / V$ and $d_{s} / b$, respectively. When the dimensionless coordinates are considered, the experiments may be grouped according to the point that the velocity measurements were carried out, such that, the D1-D4 experiments were realized at point $A(1.50,0.20)$ and D5 experiment was performed at point $\mathrm{B}(1.17,0.20)$. The variation of $V_{z} / V$ with $d_{s} / b$ is given for these two grouped data in Figure 11 and Figure 12. The obtained $R^{2}$ valuesfor linear trend line equations are 0.85 and 0.87 for the data groups $\mathrm{A}$ and $B$, respectively. It is observed that the slope of the linear trend line increases in the vicinity of the pier, especially for group B having the largest one. This indicates that the velocity near the scour is affected more from the scour hole development when compared with those which are away from the pier.

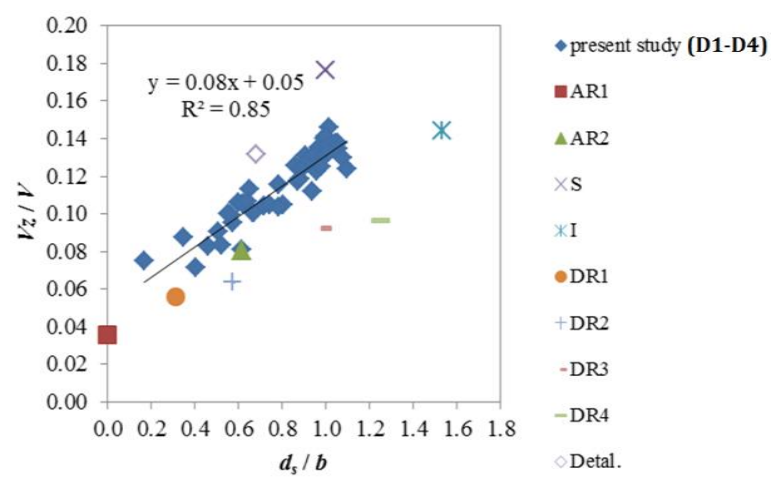

Figure 11: The variation of dimensionless vertical velocity component $\left(V_{z} / V\right)$ with dimensionless scour depth $\left(d_{s} / b\right)$ at point A $(1.50,0.20)$.

The conditions for similar studies in literature were considered in order to compare with the results of present study and properties of them are summarized in Table 2 [21],[20],[22],[23],[24]. The non-dimensional vertical velocity and scour depths were calculated and depicted on the Figure 11 and Figure 12.

Ahmed and Rajaratnam (1998)'s experiment C2R represents the velocity distribution for the fixed bed with rough surface and $\mathrm{C} 2 \mathrm{M}$ for the mobile bed [21]. Dey and Raikar (2007) conducted the velocity measurements at scour depths having the $25 \%, 50 \%, 75 \%$ and $100 \%$ of the final equilibrium scour depths have been reached [23]. Inorder to make the literature data comparable with the present study, the scour depths at $70^{\circ}$ and the approach depths at $(B-b) / 2$ upstream of the pier were calculated. Here $B$ is flume width.

The results obtained in this study are in accord with the ones obtained by Ahmed and Rajaratnam (1998), Sarker (1998), Istiarto
(2001) and Das et al. (2013) whereas the $d_{s} / b$ values of Dey and Raikar (2007) remains lower than suggested correlation. According to Melville (1997), the maximum scour depth is $2.4 b$ while the maximum in this study is $1.1 b$ [37]. Therefore the validity of the obtained correlation should be tested for larger $d_{s} / b$ ratios. The practical application of the results are limited to experimental conditions summarized in Table 3.

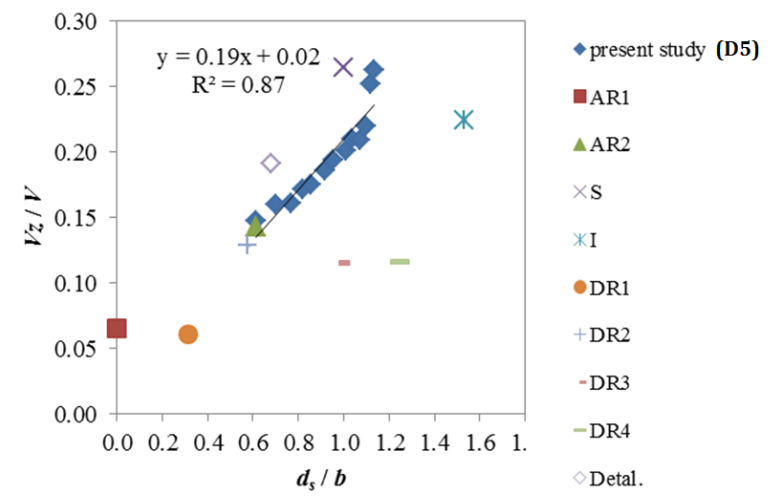

Figure 12: The variation of dimensionless vertical velocity component $\left(V_{z} / V\right)$ with dimensionless scour depth $\left(d_{s} / b\right)$ at point B $(1.17,0.20)$.

Table 2: Test conditions of the studies in literature.

\begin{tabular}{lccccccc}
\hline $\begin{array}{c}\text { Ref } \\
(*)\end{array}$ & $\begin{array}{c}b \\
(\mathrm{~cm})\end{array}$ & $\begin{array}{c}V \\
(\mathrm{~cm} / \mathrm{s})\end{array}$ & $\begin{array}{c}V / V_{c} \\
(\mathrm{~cm} / \mathrm{s})\end{array}$ & $\begin{array}{c}H_{k} \\
(\mathrm{~cm})\end{array}$ & $\begin{array}{c}d_{50} \\
(\mathrm{~mm})\end{array}$ & $\mathrm{Re}$ & $\mathrm{Fr}$ \\
\hline AR1 & 8.9 & 29.3 & 0.38 & 18.2 & 1.84 & 26077 & 0.22 \\
AR2 & 8.9 & 29.3 & 0.38 & 18.2 & 1.84 & 26077 & 0.22 \\
S & 6 & 17 & - & 30 & 0.8 & 10200 & 0.10 \\
I & 15 & 43 & $\sim 1$ & 18 & 2.1 & 64500 & 0.32 \\
DR1 & 12 & 35.7 & 0.95 & 25 & 0.81 & 42840 & 0.23 \\
DR2 & 12 & 35.7 & 0.95 & 25 & 0.81 & 42840 & 0.23 \\
DR3 & 12 & 35.7 & 0.95 & 25 & 0.81 & 42840 & 0.23 \\
DR4 & 12 & 35.7 & 0.95 & 25 & 0.81 & 42840 & 0.23 \\
Detal. & 11 & 24.7 & 0.68 & 12.5 & 0.83 & 21170 & 0.22 \\
\hline AR1:Ahm
\end{tabular}

AR1 : Ahmed and Rajaratnam (1998) C2R, AR2: Ahmed and Rajaratnam (1998) C2M S: Sarker (1998), I: Istiarto (2001), DR1: Dey and Raikar (2007) $0.25 d_{\text {se }}$ DR2: Dey and Raikar (2007) $0.5 d_{s e}$, DR3: Dey and Raikar (2007) $0.75 d_{s e}$, DR4: Dey and Raikar (2007) $d_{s e}$, Detal. : Das et al. (2013), [20]-[24].

Table 3: Limitations of this study.

\begin{tabular}{cc}
\hline Parameter & Range for present study \\
\hline$b$ & $6-9$ \\
$b / H_{k}$ & $0.29-0.44$ \\
$V / V_{c}$ & $0.78-0.91$ \\
$\operatorname{Re}$ & $13980-24570$ \\
$\mathrm{Fr}$ & $0.17-0.19$ \\
\hline
\end{tabular}

\section{Conclusions}

Scour at bridge piers, is one of the main reason for the collapse of bridges. The vertical velocity component mobilizes the sediment around the bridge pier and causes the scour development. Two circular bridge piers having diameters of $6 \mathrm{~cm}$ and $9 \mathrm{~cm}$ were located in the flume. Totally 5 experiments were conducted which continued for 4 hours. The time variation of velocity and scour depth were simultaneously measured and recorded. The scour time $\left(d_{s}-t\right)$ and vertical velocity-time $\left(V_{z}-t\right)$ graphs were obtained and it is aimed to obtain the relation between $\left(d_{s}\right)$ and $\left(V_{z}\right)$. Both of the parameters were made dimensionless and grouped according to the coordinates of the measurement point locations. It is revealed the $V_{z} / V$ value increases rapidly with $d_{s} / b$ in the vicinity of the pier.

The data belong to the two groups were compared with the literature values in the same graph. It is revealed that the equation 
of the trend line is in accord with the literature. The linear variation of the two dimensionless parameters was obtained for the range where $d_{s} / b<1.1$. Even though this study will provide an experimental data basis for numerical simulations, in the future more experiments should be conducted with different pier size and shapes at different locations in front and around the pier especially for beyond the value of $d_{s} / b=1.1$

\section{Acknowledge}

Authors thank to Assoc. Prof. Şebnem ELÇİ for providing the ultrasonic instrument for velocity measurement.

\section{References}

[1] Yanmaz M. "Yıkılan akarsu köprüleri üzerine görüşler". Türkiye Mühendislik Haberleri, 420-421-422, 4-5-6, 137-141, 2002.

[2] Shirhole AM, Holt RC. "Planning for a Comprehensive Bridge Safety Program". Transportation Research Record 1290, Transportation Research Board, National Research Council, Washington, DC, USA, 1991.

[3] Yanmaz M. Koprü Hidroliği. Ankara, Türkiye, METU Press, 2002.

[4] Sümer BM, Christiansen N, Fredsoe J. "Influence of crosssection on wave scour around piles". Journal of Waterway, Port, Coastal, and Ocean Engineering, 119(5), 477-495, 1993.

[5] Melville BW, Chiew YM. "Time scale for local scour at bridge piers". Journal of Hydraulic Engineering, 125(1), 59-65, 1999.

[6] Oliveto G, Hager WH. "Further results to time-dependent local scour at bridge elements". Journal of Hydraulic Engineering, 131(2), 97-105, 2005.

[7] Lim SY. "Equilibrium clear-water scour around an abutment". Journal of Hydraulic Engineering, 123(3), 273-243, 1997.

[8] Ettema R. "Scour at Bridge Piers". School of Engineering, University of Auckland, Auckland, New Zealand, 216, 1980.

[9] Lauchlan CS. Pier Scour Countermeasures, Ph.D. Thesis, University of Auckland, Auckland, New Zelland, 1999.

[10] Breusers HNC, Raudkivi AJ, Scouring, 1st Ed., AA. Balkema Rotterdam, Brookfield, 1991

[11] Baker CJ. "Laminar horseshoe vortex". Journal of Fluid Mechanics, 95(2), 347-367, 1979.

[12] Baker CJ. "The turbulent horseshoe vortex". Journal of Wind Engineering Industrial Aerodynamics, 6(1-2), 9-23, 1980.

[13] Baker CJ. "The position of points of maximum and minimum shear-stress upstream of cylinders mounted normal to flat plates". Journal of Wind Engineering Industrial Aerodynamics, 18(3), 263-274, 1985.

[14] Yulistiyanto B. "Velocity measurements on flow around a cylinder". Dinamika Teknik Sipil, 9(2), 111-118, 2009.

[15] Dargahi B. "Controlling mechanism of local scouring". Journal of Hydraulic Engineering, 116(10), 1197-1214, 1990.

[16] Melville BW. "Local Scour at Bridges Sites". School of Engineering, University of Auckland, Auckland, New Zealand, 117, 1975.

[17] Melville BW, Raudkivi AJ. "Flow characteristics in local scour at bridge piers". Journal of Hydraulic Research, 15(4), 373-380, 1977.

[18] Qadar A. "The vortex scour mechanism at bridge piers". Proceedings ICE Res. Theory, 71(3), 739-757, 1981.

[19] Muzzammil M, Gangadharaiah T. "The mean characteristics of horseshoes vortex at a cylindrical pier". Journal of Hydraulic Research, 41(3), 285-297, 2003.
[20] Sarker MA. "Flow measurement around scoured bridge piers using acourstic doppler velocimeter (ADV)". Flow Measurement and Instrumentation, 9(4), 217-227, 1998.

[21] Ahmed F, Rajaratnam N. "Flow around bridge piers". Journal of Hydraulic Engineering, 124(3), 288-300, 1998.

[22] Istiarto I. Flow Around a Cylinder in a Scoured Channel Bed. Ph.D. Thesis, École Polytechnique Fédérale de Lausanne, Lausanne, Switzerland, 2001.

[23] Dey S, Raikar VR. "Characteristics of horseshoe vortex in developing scour holes at piers". Journal of Hydraulic Engineering, 133(4), 399-413, 2007.

[24] Das S, Das R, Mazumdar A. "Comparison of characteristics of horseshoe vortex at circular and square piers". Research Journal of Applied Sciences, Engineering and Technology, 5(17), 4373-4387, 2013.

[25] Unger J, Hager WE. "Down-flow and horseshoe vortex characteristics of sediment embedded bridge piers". Experiments in Fluids, 42(1), 1-19, 2007.

[26] Diab R, Link 0, Zanke U. "Experimental investigation of 3D flow field around square pier". 33 rd IAHR Congress: Water Engineering for a Sustainable Environment, Canada, 2009.

[27] Saçan C, Çetin OK, Bombar G. "Investigation of the scour inception around a circular bridge pier". $2^{\text {nd }}$ International Conference on Water, Energy and the Environment, Kusadasi, Turkey, 21-24 September 2013.

[28] Bombar G. "Clear-Water bridge scour under triangularshaped hydrographs with different peak discharges". 2014 River Flow Conference, Lausanne, Switzerland, 2014.

[29] Bombar G. "The hysteresis and shear velocity in unsteady flows". Journal of Applied Fluid Mechanics, 9(2), 839-853, 2016.

[30] Yulistiyanto B. Flow Around a Cylinder Installed in a Fixed-Bed Open Channel. Ph.D. Thesis, École Polytechnique Fédérale de Lausanne, Lausanne, Switzerland, 1997.

[31] Furuichi N, Takeda Y, Kumada M. "Spatial structure of the flow through an axisymmetric sudden expansion". Experiments in Fluids, 34(5), 643-650, 2003.

[32] Blanckaert K., Flow and Turbulence in Sharp Open-Channel Bends. Ph.D. Thesis, École Polytechnique Fédérale de Lausanne, Lausanne, Switzerland, 2003.

[33] Bombar G, Kantoush S, Albayrak İ. "Comparison of ADVP and UVP in terms of velocity and turbulence measurements in a uniform flow". River Flow 2008, Ceșme, Turkey, 6-8 September 2008, Editors; M. S. Altınakar, N. Yıldırım, S. Y. Kumcu, G. Tayfur and M. Göğüş

[34] Birjukova O, Guillen S, Alegria F, Cardoso AH. "Three dimensional flow field at confluent fixed-bed open channels". River Flow 2014, Lausanne, Switzerland, 3-5 September 2014.

[35] Duma D, Erpicum S, Archambeau P, Pirotton M, Dewals B. "Flow and turbulence characterization as an onset for assessing the stability of gravel beds". River Flow 2014, Lausanne, Switzerland, 3-5 September 2014.

[36] Simarro G, Fael CMS, Cardoso AH. "Estimating Equilibrium Scour Depth at Cylindrical Piers in Experimental Studies". Journal of Hydraulic Engineering, 137(9), 1089-1093, 2011.

[37] Melville BM. "Pier and abutment scour: integrated approach". Journal of Hydraulic Engineering, 123(2), 125136, 1997. 